\title{
Marc Briod
}

Associate Professor of Education and Philosophy at Oakland University, Rochester, Michigan. His doctoral dissertation from Northwestern University was on the pedagogical implications of Heidegger's Sein und Zeit. He has recently published articles on craftsmanship and creativity, and on learning to live with equanimity by the clock. Recently completed works are on the cosmological roots of Western timekeeping and on thinking about death and time.

\section{Helmut Danner}

Privatdozent of Education at University of Munich, West Germany. Writings have mainly dealt with ethical, anthropological, and epistemological foundations of education with respect to a humanistic education and a hermeneutical and phenomenological theory of education. Books: Das Göttliche und der Gott bei Heiddeger (The Divine and Divinity in Heidegger) (1971); Methoden geisteswissenschaftlicher Pädagogik (Introduction to Hermeneutics, Phenomenology, and Dialectics) (1979); together with Langeveld: Methodologie und 'Sinn'-Orientierung in der Pädagogik (Methodology and Sense Making in Pedagogy) (1981); Verantwortung und Pädagogik (Responsibilily and Pedagogy) (1983; 1985 2nd edition); together with Lippitz (Eds.):

Beschreiben-Verstehen-Handeln (Phenomenological Investigations in Education) (1984); together with others-Zum Menschen erziehen. PestalozziSteiner-Buber (1985).

\section{Madeleine R. Grumet}

Associate Professor of Education at Hobart and William Smith Colleges.

Within the field of curriculum theory, her essays have addressed the use of autobiographical methods in educational research, esthetic models for designing, evaluating, and studying curriculum, and the relation of gender to the projects and traditions of pedagogy.

\section{Lous Heshusius}

Associate Professor, Graduate Programme in Language and Learning Problems, York University, Toronto. She holds a Ph.D. in Special Education from Indiana University. Writings have dealt with the phenomenological perspective of exceptionality, qualitative research, and with the relationship between paradigms and special education theories.

\section{Chizuko Maeda}

Doctoral student in the Department of Secondary Education at the University of Alberta. She holds a Master of Education from the University of Tokyo, and is pursuing studies concerning interpersonal activities of mentally handicapped children. She has particular interest in the question of how we can come to understandings of the lived experience of children, especially mentally handicapped children.

\section{Walter C. Parker}

Assistant Professor and Leader, Social Studies Education, in the College of Education at the University of Washington. Research and writings have focused on teachers' mediation of the curriculum, students' and teachers' conceptions of justice, and curricula that foster intellectual growth. 


\section{Adrian Peetoom}

Manager of Publications, Scholastic Publishers, Richmond Hill, Ontario. He holds degrees in the philosophy and history of education from McMaster University and from the University of Toronto, and has published articles on educational issues.

\section{Hugh J. Silverman}

Professor of philosophy and comparative literature at the State University of New York at Stony Brook. He is author of Inscriptions: Between Phenomenology and Structuralism (Routledge and Kegan Paul, forthcoming 1987); editor of Piaget, Philosophy and the Human Sciences (Humanities Press, 1980); coeditor of Jean-Paul Sartre: Contemporary Approaches to his Philosophy (Duquesne University Press, 1980), Continental Philosophy in America (Duquesne University Press, 1983), Hermeneutics and Deconstruction (Suny Press, 1985), and Descriptions (Suny Press, 1985). Professor Silverman has been executive codirector of the Society for Phenomenology and Existential Philosophy since 1980, and is also executive secretary of the International Association for Philosophy and Literature.

\section{Lize Stilma}

A writer and public relations person for several social institutions in the Netherlands. Among her works are twelve volumes of portraits about stigmatized persons, including the mentally retarded, the emotionally disturbed, abused children, drug addicts, and survivors of the concentration camps. The translations in this issue of Phenomenology + Pedagogy were selected from these volumes. For her accomplishments as a writer, Lize Stilma was awarded the "Cultuur Prijs van de Gemeente Hilversum" and received other honors such as an interview on national television and a visit with Queen Beatrix who commissioned her to write the Dutch "Year of the Child" book. Lize Stilma lives in the city of Naarden, Mozartlaan 2, the Netherlands.

\section{Kurt H. Wolff}

Manuel Yellen Professor of Social Relations, Emeritus, Brandeis University, was born in Germany where he studied under Karl Mannheim. He is the president of the International Society for the Sociology of Knowledge, an editor and translator of Georg Simmel, Emile Durkheim, and Karl Mannheim, and the author of Surrender and Catch, Beyond the Sociology of Knowledge, and other books. 